
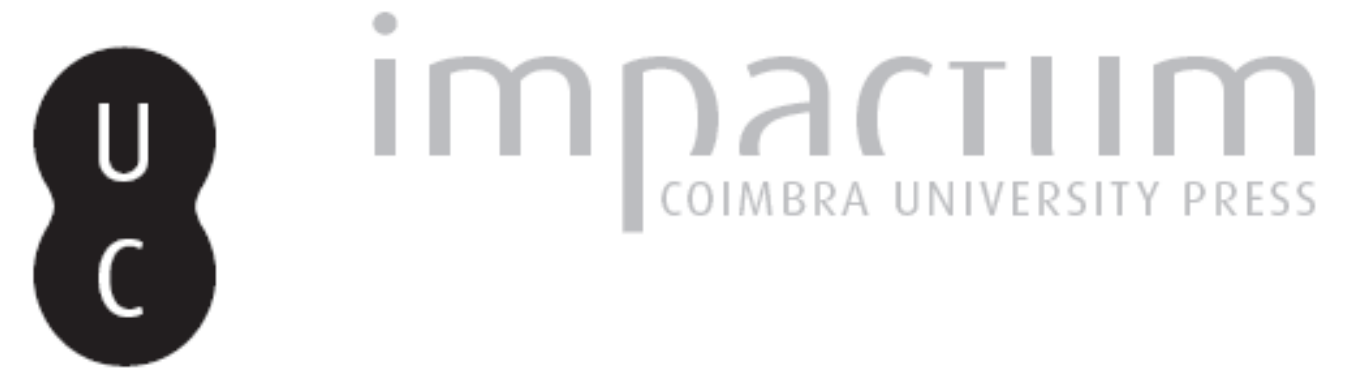

\title{
O discurso anteriano e a questão laica na Quanta Cura de Pio IX
}

\section{Autor(es): $\quad$ Enes, Maria Fernanda}

Publicado por: Imprensa da Universidade de Coimbra

URL persistente:

URl:http://hdl.handle.net/10316.2/43751

DOI:

DOI:https://doi.org/10.14195/2183-8925_13_14

Accessed : $\quad$ 26-Apr-2023 12:29:34

A navegação consulta e descarregamento dos títulos inseridos nas Bibliotecas Digitais UC Digitalis, UC Pombalina e UC Impactum, pressupõem a aceitação plena e sem reservas dos Termos e Condições de Uso destas Bibliotecas Digitais, disponíveis em https://digitalis.uc.pt/pt-pt/termos.

Conforme exposto nos referidos Termos e Condições de Uso, o descarregamento de títulos de acesso restrito requer uma licença válida de autorização devendo o utilizador aceder ao(s) documento(s) a partir de um endereço de IP da instituição detentora da supramencionada licença.

Ao utilizador é apenas permitido o descarregamento para uso pessoal, pelo que o emprego do(s) título(s) descarregado(s) para outro fim, designadamente comercial, carece de autorização do respetivo autor ou editor da obra.

Na medida em que todas as obras da UC Digitalis se encontram protegidas pelo Código do Direito de Autor e Direitos Conexos e demais legislação aplicável, toda a cópia, parcial ou total, deste documento, nos casos em que é legalmente admitida, deverá conter ou fazer-se acompanhar por este aviso.

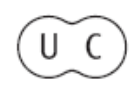


REVISTA DE HISTÓRIA DAS IDEIAS 13

\section{Antero de Quental}

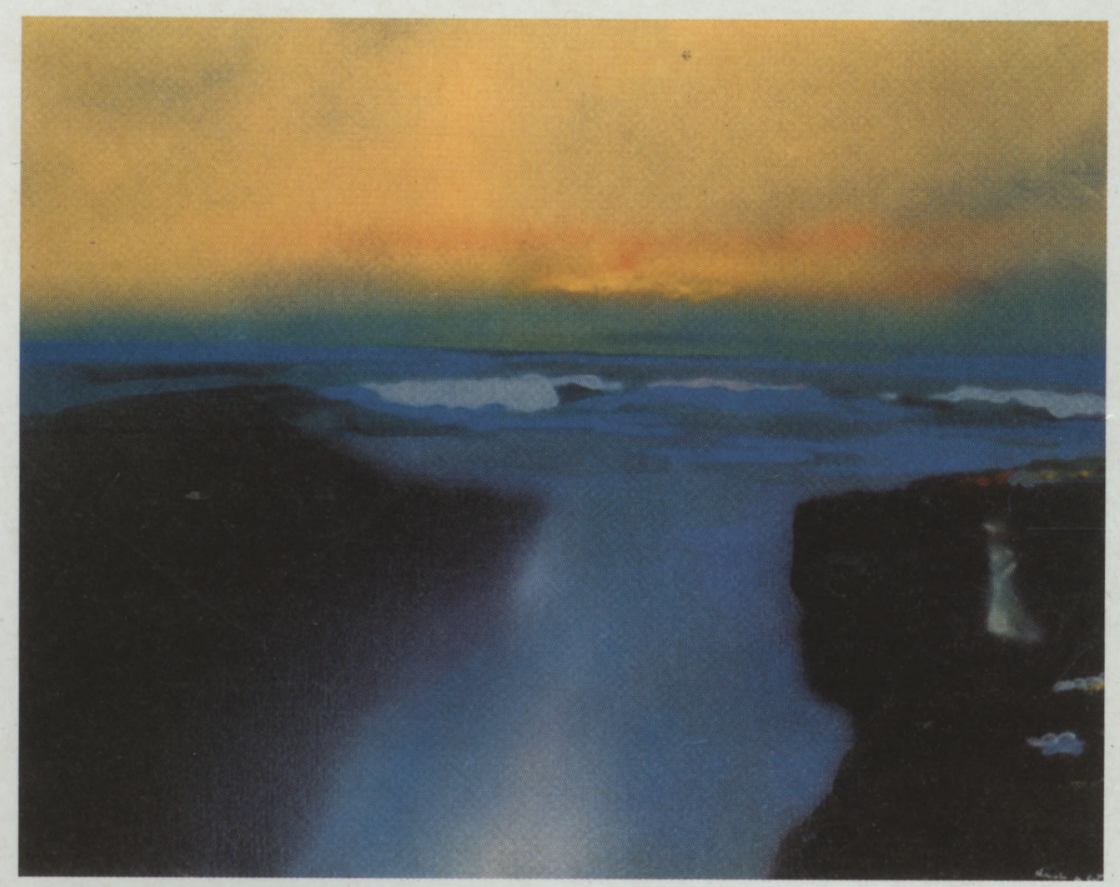

INSTITUTO DE HISTÓRIA E TEORIA DAS IDEIAS FACULDADE DE LETRAS

COIMBRA 1991 


\section{O DISCURSO ANTERIANO E A QUESTÃO LAICA NA QUANTA CURA DE PIO IX}

Antero de Quental, com o seu escrito Defesa da Carta Encyclica de Sua Santidade Pio IX contra a chamada opiniãoliberal-considerações sobre este documento $\left(^{1}\right)$ publicado em Coimbra em 1865, inscreve-se no número de pensadores laicos que denunciam a Igreja Católica como instituição imóvel e estruturalmente oposta ao ideário liberal. Nesse mesmo ano, vêm a lume as Odes Modernas e como sua sequela eclode a Questão Coimbrãa que segundo Joel Serrão é o palco da ruptura com o passado: "recusa do status quo ideológico, cristalizado simbolicamente em Castilho, como Antero cristaliza a nova ordem" ${ }^{2}$ ).

Na Nota Final às Odes, Antero proclama a Revolução como objectivo histórico "porque Revolução é o nome que o sacerdote da história, o tempo, deixou cair sobre a fonte fatídica do nosso século" ( $\left.{ }^{3}\right)$. Aí ele traça o programa de actuação: "denunciar e desvendar o passado"; preconiza que se ensine às novas gerações "as máximas do livre-exame e da independência"; exorta a imprensa a dissertar sobre "os direitos da palavra e a omnipotência da opiniăo" $\left({ }^{4}\right)$. Semelhante programa justifica e explica a recepção que faz à encíclica Quanta Cura, na medida em que a doutrina aí expendida se situa nos antípodas do seu

* Universidade dos Açores.

(') 2." ed., Imprensa Litteraria, 1865.

(2) "Génese e estrutura do pensamento sócio-político de Antero de Quental" in Antero de Quental, Prosas sócio-políticas. Publicadas e apresentadas por Joel Serrão, Lisboa, INCM, 1982, p. 45.

(3) Idem, ob. cit., p. 195.

(4) Idem, ob. cit., p. 196. 
"programa", bem como o ataque à opinião liberal que se rebela contra Pio IX, seu autor.

A atitude de Antero de Quental face à tradição e a sua fogosidade "iconoclasta", dos anos sessenta, alcançam inteligibilidade no interior de uma década bem caracterizada pelo espírito laico. Embora a confraternização entre laicos e católicos em 1848, dentro de um ideal romântico de liberdade e igualdade radicado a um tempo no Evangelho e na Revolução, se tenha apresentado como uma primavera de relações amistosas entre a antiga e a nova ordem, que o Segundo Império parecia continuar, o facto é que essa união não era sólida. Se o Evangelho pode ser e é fundamento da liberdade, igualdade e fraternidade, a prática governativa da Igreja, ao longo de uma história de mais de dezoito séculos, e a sua doutrina legitimadora do poder, onde assentavam as teorias de direito divino, não se coadunavam com a nova ordem, assente na soberania popular e no direito à liberdade de pensamento e de expressão.

Assim, o confronto entre a ideologia católica e a ideologia liberal tornava-se inevitável. A Declaração dos Direitos do homem e do cidadão ou o "Evangelho dos novos tempos" ( $\left.{ }^{5}\right)$ em 1789 instaurara uma supranacionalidade assente no direito natural, universal como a católica, cujo fundamento era o direito divino e a Revelação.

O Segundo Império em França, país paladino das novas ideias, (é esse o sentido das campanhas napoleónicas que Napoleão III pretende, em novos moldes, reeditar, apoiado de começo pelos católicos), mascara, como na II República, uma situação de apaziguamento entre aquelas duas supranacionalidades. A questão romana, em que Napoleão III quis ser árbitro $\left(^{6}\right)$, materializava aquele confronto. Como conciliar o apoio ao poder temporal, que a Igreja defendia ser necessário à sua missão espiritual, quando impedia o direito natural do povo italiano à sua nacionalidade?

As cedências do Imperador de França à união de Itália provoca 0 descontentamento dos católicos que se voltam para Pio IX, o Papa-mártir. Embora a proteç̧ão de Napoleão ao Pontífice fossevmais forte

(5) Cf. Histoire de la France, dir. André Bourguière et Jacques Revel, "L'État et ses pouvoirs", dir. Jacques Le Goff, Paris, Ed. du Seuil, 1989.

${ }^{6}$ ) Ver a este propósito G. de Bertier de Sauvigny, Histoire de France, Paris, Flammarion, 1977, p. 370 ss. 


\section{A Questão Laica na "Quanta Cura"}

do que o seu apoio à união de Itália, não o impediu que em 1864 assinasse a Convenção de 15 de Setembro com Víctor Emanuel, na qual se comprometia a retirar as suas tropas de Roma. Pio IX interpreta este facto como sinal de abandono da Igreja por parte da França ( $\left.{ }^{7}\right)$. De facto, quando em 1866 se dá a evacuação de Roma do exército francês, Garibaldi invade-a de imediato.

A Convenção de 1864, porém, não significou o efectivo abandono do Papa pelo Imperador. Todavia, a sua política ambígua provocara descontentamentos tanto por parte dos católicos como dos liberais. Os primeiros sentem-se traídos, os segundos explorados, tanto mais que o tesouro de França é afectado rudemente com aquela campanha $\left({ }^{8}\right)$. A questão romana provocou uma aproximação sem precedentes dos católicos a Roma. É a eclosão, em tempos de descristianização, de uma autêntica devoção popular ao Sumo Pontífice $\left({ }^{9}\right)$. Mais do que nunca se torna no Chefe Visível da Igreja para o qual convergem não só as preces e o pensamento mas também os crentes em peregrinação e o dinheiro da cristandade - o dinheiro de São Pedro $\left({ }^{10}\right)$.

Se o Papa foi nos séculos recuados da Idade Média e da Moderna o árbitro dos povos a "lei internacional", agora, no momento histórico em que lhe é contestada a temporalidade do seu poder, transforma-se para uns em "ídolo" e para outros no símbolo do passado. Nele se confrontam a antiga e a nova ordem. São os anos do isolamento da Igreja $\left({ }^{11}\right)$, mas também os da piedade popular sobretudo por parte da grande massa dos católicos rurais, orientados pelo clero ultramontano.

Neste contexto não só à Igreja-instituição é negada a legitimidade do poder temporal $\left({ }^{12}\right)$ como se vê confrontada com uma "formidável

\section{$\left({ }^{7}\right)$ Ibidem.}

${ }^{(8)}$ Segundo Bertier de Sauvigny a política externa de Napoleão, que ao tempo pareceu o aspecto mais forte do seu reinado, na medida que satisfazia o orgulho da França chauvinista, foi de facto o aspecto mais negativo do II Império, ob. cit., p. 365.

$\left({ }^{9}\right)$ Cf. Paul Gerbod, L'Europe culturelle et religieuse, Paris, PUF, 1977.

$\left({ }^{10}\right)$ Nome dado ao dinheiro enviado pelas dioceses do mundo católico a Roma, fruto de peditórios regulares a favor de Sua Santidade. -225 .

(") Pierre Pierrard, L'église et les ouvriers en France, Paris, Hachette, 1984, p. 215 -

(') A brochura Le Pape et le Congrès (1860) mostra que Napoleão III "non seulement ne voulait pas imposer aux Romagnes la domination du pape, mais qu'il était hostile au pouvoir temporel dans sa forme traditionnel", in Jean Maurám, La Politique écclésiastique du Second Empire, Alcan, 1930, apud Pierre Pierrard, ob. cit., p. 225 ss. 
vaga de anticlericalismo e de irreligião" $\left({ }^{13}\right)$ que en 1871 a Comuna leva ao paroxismo. Numerosas foram as publicações que contrapunham 0 ideário revolucionário ao cristão. A Revolução, com os seus valores e os seus princípios, constitue a referência substitutiva e oposta ao catolicismo. Michelet com a publicação em 1864 da sua obra La Bible de l'Humanité, a propósito da qual Antero irá elaborar a sua "via própria sobretudo no que toca à função do cristianismo" $\left({ }^{14}\right)$, e a grande difusão da História da Revolução Francesa $\left({ }^{15}\right)$, ao lado de Ernest Renan, que publica La Vie de Jésus em $1863\left({ }^{16}\right)$, representam a ruptura com o cristianismo.

Muitos são os autores que acompanham Michelet em versões múltiplas da história da Revolução Francesa, destinadas ao grande público, tendo em vista a exaltação e glorificação da soberania popular instauradora da liberdade, igualdade e fraternidade. Juntam-se a esta produção histórica outras. Umas de cariz social que têm, na obra paradigmática de Proudhon De la justice dans la Révolution et dans l'Église (1865), a sua expressão máxima; outras de cariz científico dominado pelo positivismo e pela exegese e filosofia alemãs, reflectindo as descobertas das novas disciplinas científicas.

Nesta década de sessenta as teorias evolucionistas de Boucher de Perthes, Darwin, Lamarck e da fisiologia de Claude Bernard e Paul Bert dão solidez ao relativismo científico e ao divórcio entre religião e ciência $\left({ }^{17}\right)$ que a Crise da Consciência Europeia $\left({ }^{18}\right)$ começara por debater abertamente. Como diz René Rémond: "Si, jusqu'à la veille de la Révolution de 1848, il (l'anticlericalisme) puisait ses principes dans la philosophie des Lumieres et vivait sur ses systèmes de pensée que l'apologétique chrétienne se plaisait à dénnoncer comme surannés, le

$\left({ }^{13}\right)$ Para o caso francês ver P. Pierrard, ob. cit., p. 219.

$\left({ }^{14}\right)$ "Comentário" de Joel Serrão in Antero de Quental, Obras Completas, III Filosofia, organização, introdução e notas de Joel Serrão, UAVed.Comunicação, 1991, p. 177.

$\left({ }^{15}\right)$ Começada a publicar em 1847 , interrompida durante o ano revolucionário de 1848 e retomada de 1849 a 1853, conforme Michelet, História da Revolução Francesa, vol. I, trad. portuguesa de P.E.A. da ed. Robert Laffont, Paris, 1979, e conhece a sua $6^{\circ}$ edição em 1864. Cf. P. Pierrard, ob. cit., p. 216.

$\left.{ }^{16}\right)$ Em 1869 está já publicada a 13 edição. Cf. Ernest Renan, Questions Contemporaines, Paris, Michel Lévy Frères, ed., 1869.

$\left({ }^{17}\right)$ P. Pierrard, ob. cit., p. 216.

$\left.{ }^{18}\right)$ Referência à obra clássica de Paul Hazard, Crise da Consciência Europeia, Lisboa, ed. Cosmos, 1978. 


\section{A Questão Laica na "Quanta Cura"}

rapport s'inverse dans la seconde moitié du XIX siècle. Le catholicisme néglige l'éffort intellectuel, tandis que se produit un renouvellement de sources de l'incroyance. De nouvelles écoles de pensée, de nouveaux systèmes philosophiques arment l'anticlericalisme qui devient irreligion convaincu, incroyance systématique, athéisme réflechi" ( $\left.{ }^{19}\right)$.

A difundir e expandir este confronto entre a doutrina tradicional e a nova supranacionalidade, fundamentada no homem e nos seus direitos "naturais, inalienáveis e sagrados", como a Declaração dos Direitos do homem e do cidadão os reconhecera em 1789 e que a Constituição de 1848 em França definira "como superiores às leis positivas" $\left({ }^{20}\right)$, aparece uma autêntica vaga de periódicos que transforma as ideias nas armas de um combate que, se bem que tendo atravessado todo o século, agora se agudiza. Le temps de la prêtrophobie ou l'Église attaquée de partout são títulos de parágrafos que Pierre Pierrard utiliza ao historiar a emergência, vigor e por vezes cólera da imprensa laica e cristã que, ao degladiar-se, procura impôr, cada um por seu turno, a sua própria ideologia. Dum lado o exército dos crentes que se defende e ataca "la tourbe ignoble de rédacteurs de journaux impies e démoralisateurs", do outro o dos laicos que ataca sem cessar os vícios, a imbecilidade e a imobilidade dos cristãos, sobretudo dos católicos e, dentre estes os ultramontanos $\left({ }^{21}\right)$.

No contexto do Segundo Império, tão aparentemente favorável à Igreja, extremam-se as posições entre a nova e a antiga ordem: "le culte de la science se substitue à la religion" ${ }^{22}$ ) e Roma torna-se o símbolo da reacção. De notar, porém, que nos Açores mesmo por parte da imprensa liberal, como é o caso de A Persuasão, que na década de sessenta mantêm acesa polémica com periódicos ultramontanos, considerados jesuíticos como a Voz da Verdade ou simplesmente católicos como a Ilha, considera a difusão das obras irreligiosas uma consequência da condenação da Igreja. Diz expressamente que livros como os de Voltairee Diderot no século XVIII ou de Renan noXIX "tão avidamente lidos enquanto as censuras e prohibições dificultavam a sua aquisição

$\left.{ }^{(19}\right)$ L'Histoire de l'anticlericalisme en France de 1815 à nos jours, Paris, ed. Complexe, 1979, p. 126 (sublinhado nosso).

$\left({ }^{20}\right)$ Cf. art. 3 do Preâmbulo, ob. cit., por Émile Poulat, Liberté, laicité, Paris, Éd. du Cerf, 1987, p. 21 ss.

(21) P. Pierrard, ob. cit., pp. 218-228.

(22) Ibidem, p. 126. 
e dos quaes ninguém hoje faz caso, religiosamente falando não possuiríamos tantos monumentos de litteratura christã, de que justamente nos devemos ufanar" $\left.{ }^{23}\right)$. Vai ainda mais longe ao afirmar "as armas empregadas contra a religião christã só ferem a reputação de quem as empunha..." $\left.{ }^{24}\right)$.

\section{A Quanta Cura e o Syllabus}

Roma torna-se, de facto, o símbolo da reacção face às máximas da sociedade moderna consagradas nos Direitos do homem e do cidadão. A Igreja que tradicionalmente fora a defensora e instauradora da liberdade e da dignidade do homem, encontra-se frente a valores idênticos aos por ela defendidos, legitimados agora por princípios laicos.

Por outro lado o Estado Romano representa um obstáculo às aspirações do povo italiano a um direito justo e liberal - o de se tornar nação. A obstinação da Igreja em manter o poder temporal significa a recusa do seu papel exclusivamente espiritual e de religião intimista, pelo que ela própria tanto lutara.

A publicação da Carta Encíclica Quanta Cura de 8 de Dezembro de 1864, dois meses após a assinatura da Convenção com Víctor Emanuel pelo Imperador, e do catálogo de erros do liberalismo-Syllabus - vem coroar a reacção da Igreja, na sequência da Encíclica Mirari vos de 1832 a qual condenara já uma ideologia "que rejeita qualquer princípio teologico para a realidade, sujeitando-a unicamente ao domínio exclusivo da razão" $\left({ }^{25}\right)$.

A encíclica de Pio IX é mais explícita, que a sua congénere anterior, na condenação dos erros modernos. São os valores da nova ordem liberal e da supremacia da razão humana e da ciência que aí são renegados. São eles: o racionalismo, o regalismo, o estatismo, o socialismo, o naturalismo $\left({ }^{26}\right)$.

O que está em causa na Quanta Cura é a afirmação da autoridade

$\left({ }^{23}\right)$ A Persuasão, Ponta Delgada, n. ${ }^{\circ} 133$ de 13 de Julho de 1864.

(24) Ibidem.

$\left.{ }^{25}\right)$ António Manuel Martins, "Recepção em Portugal das Encíclicas sobre o Liberalismo: Mirari vos, Quanta cura e Imortali Dei", Lusitânia Sacra, 2." série, 1989, p. 45.

$\left({ }^{26}\right)$ Ibidem, p. 55. 
revelada que, na sociedade de regime liberal regalista, racionalista e naturalista, se vê substituída pela autoridade da razão natural: os direitos inalienáveis e sagrados dos cidadãos.

A situação concreta de grandes dificuldades materiais e políticas, causados pela questão romana a par do ataque sistemático que lhe é movido pelos liberais, explicam a excessiva dureza e voluntário ostracismo da Igreja face à evolução da civilização moderna.

A recepção que o mundo católico faz ao documento papal é entusiasta por parte dos integristas, mas moderada e titubeante por parte da maioria do clero que aceita o liberalismo. Assim, em Portugal seoAmigo da Religião tenta justificar a doutrina da encíclica, procurando não hostilizar a doutrina papal sem se opor ao liberalismo vigente, $A$ $N a c ̧ a ̃ o$ acolhe-a entusiasticamente. Por sua vez a maioria dos periódicos da imprensa liberal, moderada ou radical, é praticamente unânime em criticar o texto da encíclica Quanta Cura e do Syllabus $\left({ }^{27}\right)$. Qualifica o texto de reaccionário, de "inconciliável com o progresso e com a civilização moderna" segundo expressão de $O$ Jornal de Lisboa $\left({ }^{28}\right)$. A interpretação que o Jornal do Comércio, a Gazeta de Lisboa $\left({ }^{29}\right)$ e o Angrense $\left({ }^{30}\right)$ fazem do referido texto é no sentido de o associar à questão romana, à defesa do poder temporal. A Gazeta de Portugal encara-o "não como dogma ou lei da egreja" mas como "negócios políticos de primeira ordem (...) o poder temporal, e nesse o papa defende tenazmente a herança que lhe transmitiram os seus predecessores" $\left.{ }^{(31}\right)$. O Jornal de Commercio, por sua vez, considera tratar-se de uma "resposta da cúria romana à convenção franco-italiana, de 15 de Setembro; a luta lançada pela reacção política, coberta com o manto da religião a todas as pessoas e a todos os governos liberais" ${ }^{32}$ ). É neste sentido que o Angrense $\left({ }^{33}\right)$ vê este documento "como que a bandeira que o papa desfralda aos ventos tempestuosos do século XIX para em torno d'ella reunir todos os sectário do direito divino e da escravidão dos povos".

\footnotetext{
$\left({ }^{27}\right)$ Ver o estudo referido.

$\left({ }^{28}\right)$ Artigo transcrito em $A$ Persuasão, n. ${ }^{\circ}$ 163, 8 de Fevereiro de 1865.

${ }^{(29}$ Transcritos in Ibidem.

$\left.{ }^{(30}\right)$ In n. ${ }^{\circ} 1307$ de 4 de Fevereiro de 1865.

( $\left.{ }^{31}\right)$ In A Persuasão, n. ${ }^{\circ} 163$ de 4 de Fevereiro de 1865.

( ${ }^{32}$ Ibidem.

$\left({ }^{33}\right)$ N. ${ }^{\circ} 1317$ de 15 de Abril de 1865.
} 
O Jornal do Commercio acrescenta algo mais a esta interpretação. Afirma que a encíclica ao condenar toda a liberdade, toda a ideia de soberania popular"verdadeiramentee menos dirigida contra os ímpios do que contra os católicos liberais, contra a eschola de Montalembert, contra os que ousam dizer-se defensores do Papa sendo liberais" $\left.{ }^{34}\right)$.

Se a hostilidade da imprensa, não só de Portugal como de toda a Europa, na afirmação de $A$ Persuasão "com excepção de poucos jornaes que representam ainda as ideias da theocracia intolerante que n'outras épochas avassalou os povos", vêem na encíclica um documento de guerra declarada aos "princípios liberais sobre que assentam as sociedades modernas" ${ }^{35}$ ), nem todos atacam o Papa como chefe espiritual. $\mathrm{O}$ artigo, já citado, do Jornal de Commércio tenta separar a Igreja, os católicos e "o respeito devido às virtudes particulares do bondoso pastor". De igual modo no Angrense, o jornal açoriano que mais espaço dedica a este tema, pode ler-se: "o papa rei, o papa senhor das consciências, o papa dominador dos povos e dos reis, o papa infallível, o papa armado de espada, desapparecerá com todo o seu cortejo das doutrinas inauguradas por Gregório VII; mas há-de ficar o papa pastor, o papa pae dos fiéis, o papa que empunha o báculo, o papa vigário da Egreja, o papa homem, o papa segundo o Evangelho - e o verbo divino cumprir-se-a" $\left({ }^{36}\right)$.

Muito pouco de irreligioso existe nestes textos, não obstante a forte reacção ao texto anti-histórico da encíclica que condena não só o liberalismo como o catolicismo liberal. Se bem que a Quanta Cura e o Syllabus condenem todos os governos que "hoje correm atraz d'uma civilização fundada no progresso que é desvioconstante do catholicismo, e amam o liberalismo que é exclusão systemática da ordem sobrenatural" $\left({ }^{37}\right)$, as motivações imediatas, que levaram à redacção das encíclicas contra o liberalismo, referem-se ao catolicismo liberal.

O primeiro destes documentos visara essencialmente o complexo catolicismo mennaisiano, a um tempo ultramontano e liberal. Embora fosse a ideia de uma teocracia, "la grande unité de la société des esprits

(34) In A Persuasão, n..$^{\circ} 163$.

( $\left.{ }^{35}\right)$ Ibidem.

$\left.{ }^{(36}\right)$ Refere-se-lhe nos n. ${ }^{*} 1307$ de 4 de Fevereiro, 1314 de 23 de Março e 1317 de 15 de Abril, em longos artigos o último dos quais ocupa duas páginas.

$\left({ }^{37}\right)$ Eugénio Manuel Dias, $O$ Syllabus justificado ou a explicação do Syllabus, Lisboa, 1876, p. 169, apud António Manuel Martins, ob. cit., p. 64. 


\section{A Questão Laica na "Quanta Cura"}

entre eux et avec Dieu" $\left.{ }^{38}\right)$, que motivava Lamennais, o certo é que ele defendia a liberdade dos cultos e de ensino, princípios bem liberais. A ideia chave, a aspiração fundamental de toda a sua vida fora: "la liberté, l'independance de l'homme à l'égard de l'homme. On s'explique ainsi que le jour où le démocrate-chrétien croira constater que le Saint-Siège pactise avec le pouvoir despotique, et par conséquent fait manquer le christianisme à sa mission libérale, sa vraie raison d'être à ses yeux, il perd sa foi en hiérarchie, en Église constituée" $\left({ }^{39}\right)$.

Dentro deste espírito, lança-se com os seus discípulos Lacordaire e Montalembert no programa da Internacional católico-liberal através do L'Avennir, que está na base da Encíclica Mirari vos (1832), a primeira a visar os erros racionalistas e laicistas do liberalismo $\left({ }^{40}\right)$. Não se tratava, porém, de liberalismo vago, mas de "o amplo programa de liberdades [defendido] por Lamennais" $\left({ }^{41}\right)$.

Ora, é um discípulo de Lamennais, Montalembert que a Encíclica Quanta Cura visa em última análise. A sua obra L'Église libre dans l'État libre e a decisão do seu autor de, através de Le Correspondant "pregar a aliança da Igreja com a liberdade", tentando demonstrar que o"liberalismo pode ser compreendido num sentido perfeitamente cristão" $\left({ }^{42}\right)$, estão na base da Quanta Cura e especialmente do Syllabus. Não é sem sentido que, em nota ao erro 76 referente ao poder temporal. da Igreja, se afirma: "Todos os católicos devem permanecer firmissimamente na doutrina sobre o poder temporal do Romano Pontífice" $\left({ }^{43}\right)$.

A Igreja ao lançar o anátema sobre o seu inimigo externo, o liberalismo, não podia deixar de condenar e de exigir a retractação dos católicos que pactuavam com tal inimigo. Assim se entende a confusão que os documentos papais lançaram na Igreja de França e da Bélgica e a perturbação na hierarquia e fiéis dos restantes países $\left({ }^{44}\right)$.

\footnotetext{
$\left.{ }^{(38}\right)$ A. Fonck, "Lamennais" in Dictionnaire de Theologie Catholique, c. 2478.

${ }^{\left({ }^{39}\right)}$ La jeunesse de Lamennais, p. 692. Apud A. Fonck, ob. cit., c. 2479.

$\left({ }^{40}\right)$ António M. Martins, ob. cit., p. 42 ss.

(4) Idem, ob. cit, p. 44.

( ${ }^{42}$ Idem, ob. cit., pp. 52-54.

$\left({ }^{43}\right)$ Idem, ob. cit, p. 57.

(44) Ver a este propósito todo o estudo de António M. Martins, ob. cit..
} 


\section{Antero de Quental e a Quanta Cura}

Neste contexto, o texto anteriano, Defesa da Carta Encíclica contra a opinião liberal de 1865, logo de imediato à publicação da Quanta Cura, ganha um significado epocal e ideológico próprios, na medida em que se distancia da reacção geral, pela sua coerência e lógica, qualidades que elogia no texto papal. Sob a designação eufemística de defesa deparamos com o mais verrinoso e desabrido ataque à encíclica. Em coerência com a posição revolucionária preconizada nas Odes Modernas, em especial na Nota Final, e assumida na célebre Questão Coimbrã, Antero ataca o passado, que a Igreja significa, elogiando a coragem de Pio IX em dissociar a doutrina católica da nova doutrina que frontalmente condena. Do mesmo modo, ataca a opinião liberal por não ter coragem de ser coerente consigo mesma, ou seja, de não aceitar a sua separação, doutrinal e efectiva, da Igreja e, consequentemente, de reagir negativamente à condenação pontifícia.

No dizer de Joel Serrão, o pensamento sócio-político de Antero, por volta de 1865, "é caracterizável pelo republicanismo, pelo anarquismo, pelo ateísmo e sobretudo ele é cimentado pela aspiração de justiça" $\left.{ }^{45}\right)$. Justiça laica, entenda-se. Tanto mais que o nosso pensador substitui o terceiro termo da tríade revolucionária republicana fraternidade -, que a Revolução de 1848 romanticamente cristianizara, por justiça $\left({ }^{46}\right)$. Aliás, em "A República", artigo publicado no jornal Democracia Portuguesa, afirma que "a mesma religião é hoje republicana" $\left.{ }^{47}\right)$. Em $1862 \mathrm{em} A$ Indiferença em política ao condenar a reacção cristalizada na vaga missionária, então denominada de jesuítica $\left({ }^{48}\right)$, afirmara já que a liberdade é a "primeira condição de toda a moral e de toda a justiça" $\left({ }^{49}\right) .1862$ é também a data da publicação do artigo

${ }^{(45)}$ Prosas sócio-políticas, p. 45.

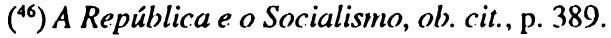

( $\left.{ }^{47}\right)$ Em Maio de 1870, ob. cit., [XII], p. 248.

$\left({ }^{48}\right)$ Este movimento alcança nos Açores um enorme eco, não só do que se passa no Continente português, mas sobretudo em termos de debate àcerca das missões realizadas em $S$. Miguel. Este debate dá-se sobretudo entre a imprensa ultramontana $A$ Voz da Verdade e a Missão, de um lado, e a imprensa liberal, moderada e católica como A Persuasão ou radical como a livre-pensante $A$ Voz da Liberdade. Este último periódico surge em resposta à Voz da Verdade.

$\left({ }^{49}\right)$ Ob. cit., [V], p. 162. 


\section{A Questão Laica na "Quanta Cura"}

Questão Romana. Aí afirma o confronto entre o passado e o presente, a antiga e a nova ordem, que nela se verifica: "é o pleito entre o obscurantismo, a intolerância e a tirania, universais inimigos do homem, e a ilustração, a tolerância e a liberdade" $\left({ }^{50}\right)$. É em nome da liberdade que defende a unidade da Itália como o "direito concedido por Deus a esses indivíduos colectivos chamados nacionalidades" $\left({ }^{51}\right)$.

A posição face à encíclica é explicada assim pelo seu pensamento fortemente laico que Antero desenvolve em dois dos seus escritos filosóficos: A Espontaneidade, de 1865, embora só tornada pública no ano seguinte ( $\left.{ }^{52}\right)$, e $A$ Bíblia da humanidade de Michelet - ensaio crítico, vindo a lume em $1865\left({ }^{53}\right)$.

A exaltação que na Espontaneidade faz da razão e da liberdade, contrapostas ao sobrenatural cristão, corresponde a uma "desentronização do sobrenatural" que no dizer do seu autor "É a grande obra do séculoXVIII". Ou seja: "o resultado desse exame universal da natureza, do espírito e da história, foi o desaparecimento do vocabulário humano de uma pequena palavra, pequena em verdade, mas pesada para a inteligência como vinte séculos de ignorância e escravidão - o sobrenatural" $\left({ }^{54}\right)$.

O sobrenatural cede lugar à "consciência e à liberdade" $\left({ }^{55}\right)$; contrapõe à "inspiração, graça e revelação", das épocas passadas, a "consciência, responsabilidade, vontade" $\left({ }^{56}\right)$. Nesta triologia Antero vê o homem como o obreiro e obra de si próprio, utilizando a citação que ele próprio faz de Renan "o espontâneo é à uma humano e divino" $\left.{ }^{57}\right)$. É de facto a adopção de uma nova ideologia substitutiva da católica tradicional.

${ }^{\left({ }^{50}\right)}$ Ob. cit., [VI], p. 165.

(51) Ob. cit., p. 166.

( ${ }^{52}$ ) Obras Completas de Antero de Quental, III. Filosofia, organização, introdução e notas de Joel Serrão, UA/ed. Comunicação, 1991, pp. 43-51.

$\left.{ }^{(53}\right)$ Ob. cit., pp. 11-25.

(54) Ob. cit., p. 43.

${ }^{(55)}$ Ibidem.

(56) Ob. cit., p. 46.

${ }^{(57)}$ "Diz Renan, o homem produz tudo o que sai da sua natureza; concorre com a sua actividade; fornece a força bruta que produz o resultado (...). O verdadeiro autor das obras espontâneas é a natureza humana, ou, se se quiser, a causa superior da natureza. Neste ponto torna-se indiferente atribuir a causalidade a Deus ou ao Homem. $\mathrm{O}$ espontâneo é à uma humano e divino", ob. cit., p. 49 
Adoptando a teoria da evolução do espírito Antero não rejeita contudo o papel do cristianismo na história da humanidade. No ensaio crítico ele chega a afirmar: "o cristianismo criou a humanidade (no grande e verdadeiro sentido da palavra)" ${ }^{(58)}$. Esta asserção cria sentido no interior do movimento na história da humanidade onde cada civilização e cada religião têm o seu espaço próprio: "a alma da humanidade em cada homem e, na humanidade, a alma inteira do mundo" $\left({ }^{59}\right)$, e onde o cristianismo detém um lugar especial. Antero explicita a sua posição relativamente a este ponto quando ao comentar a teoria do socialismo de Oliveira Martins, contesta a análise que o historiador faz da Idade Média e dos seus elementos estruturais - cristianismo e barbárie -, afirma "considero o cristianismo como essencial à evolução; mais, como o termo necessário de todo o movimento moral da antiguidade" $\left({ }^{60}\right.$ ). É de alguma forma um cristianismo (à uma humano e divino como afirmara Renan), aliás o próprio Antero diz a completar aquela sua ideia: "quero dizer, que dado o estado moral da humanidade na última época do período greco-romano, se o cristianismo não era inevitável, o que era inevitável era uma religião na essência cristã, isto é, mística" $\left.{ }^{61}\right)$.

Pode interpretar-se esta sua posição à luz da humanização da história e da divinização da humanidade na frase lapidar, que Antero deixa em itálico, ao finalizar o segundo artigo sobre $A$ Bíblia da humanidade de Michelet: "o Deus da Humanidade é o mesmo homem: e o seu ideal a religião da Vida" $\left.{ }^{(62}\right)$. Continua ainda aqui "a desentronização do sobrenatural" de que fala em Espontaneidade?

A historicidade e o papel importante do cristianismo "primeiro momento da unidade da história humana" $\left({ }^{63}\right)$, ressalta bem evidente destes seus escritos do ano da Defesa da Carta Encíclica e mesmo dos posteriores às Conferências Democráticas do Casino, como é o caso da Teoria do Socialismo, todavia trata-se de um cristianismo histórico, inserido no devir da humanidade de que o homem é obreiro: "é a nega-

\footnotetext{
( $\left.{ }^{58}\right)$ Ob. cit., p. 13.

$\left({ }^{59}\right)$ Ob. cit., p. 16.

$\left({ }^{60}\right)$ Publicado em Dezembro de 1872 no Pensamento Social, Lisboa, in Prosas socio-politicas, p. 405.

(6) Ob. cit., p. 406.

(62) Filosofia, p. 17.

( ${ }^{63}$ ) Ob. cit., p. 20.
} 


\section{A Questão Laica na "Quanta Cura"}

ção do absoluto e como tal a afirmação do homem. O Deus sai da imobilidade do símbolo inalterável; faz-se vida, move-se - é um Deus progressivo" $\left({ }^{64}\right)$.

Ao ler Antero vê-se Renan. Não a complicada filosofia de Hegel, mas a relativização do cristianismo que o exegeta francês, de escola alemã, realiza na sua obra. Tarefa só possível a um laico que vive na pátria da revogação do édito de Nantes, e consequente crise de consciência europeia, da Revolução, da Proclamação dos direitos do homem e do cidadão e ainda do desenvolvimento do espírito laico que evolui em convulsões sucessivas em todo o oitocentos.

Ora, não será sem sentido que um dos agentes da questão coimbrã, colocado do lado da tradição - Pinheiro Chagas - tome posição oposta a de Renan relativamente ao cristianismo. No artigo "Juízo crítico", sobre a obra de Renan $A$ vida de Jesus, produzido em $1864\left({ }^{65}\right)$, manifesta-se em contradição com a doutrina que Antero expendia na Defesa da Carta Encíclica e nos outros seus escritos contemporâneos. Porque não ver nos ataques a Renan também um ataque velado a Antero? Pinheiro Chagas ataca: "o homem que ousou tocar na arca santa das nossas tradições religiosas; o homem que depois de volvidos dezanove séculos, apagou o facho da fé, e penetrou com essa lanterna de luz mortiça, que se chama rasão, lanterna que uma armadura de ferro preserva cuidadosamente do vento do entusiasmo, nas trevas históricas; o homem que n'esse labyrintho do passado despresando o fio habitual que tem servido de guia à humanidade, intenta dirigir-se por outra maneira, não pode destruir com o simples argumento ' $E$ sobrenatural, logo é falso' o que imensas gerações tem acolhido e acreditado" $\left({ }^{66}\right)$.

Pinheiro Chagas ataca Renan sobretudo por este pôr em causa a luz da revelação, por ter humanizado Cristo e consequentemente o cristianismo: "o edifício em que as gerações se abrigaram durante séculos, edifício inundado pela imensa luz da revelação, desmoronou-se e a humanidade perdida de novo no deserto da dúvida, tem de se abrigar no seu caminhar desesperado e atónito, debaixo da tenda da phyloso-

( $\left.{ }^{4}\right)$ São as palavras de abertura do $2 .^{\circ}$ artigo de A Bíblia da Humanidade de Michelet - ensaio crítico, p. 17.

${ }^{(65)}$ Transcrito sob a epígrafe "Folhetim" no semanário A Persuasão de Ponta Delgada, com início no n. 133 de 13 de Julho de 1864.

${ }^{(66)}$ N. ${ }^{\circ} 135$ de 27 de Julho de 1864. 
phia, tenda oscilante e agitada constantemente pelos vendavais encontrados dos raciocínios... Não é possível que este homem ponha a túnica de charlatão nos hombros de Jesus" $\left({ }^{67}\right)$. .

A insistência que aqui se faz no que nos parece ser um paralelismo entre as posições de Renan e de Antero não se baseiam somente em $L a$ Vie de Jésus, onde o pensador francês nega a divindade de Cristo, atacando o sobrenatural, nem tão pouco nas referências que o nosso poeta-filosofo faz à $L^{\prime}$ Origine du Langage $\left({ }^{(68}\right)$ mas essencialmente no teor da Carta Encíclica.

Antero utilizando um estilo panfletário apresenta na força incisiva e persuasiva das suas afirmações e negações os argumentos que Renan desenvolvera há mais de vinte anos no escrito $D u$ liberalisme Clerical $\left.{ }^{(69}\right)$. Nele, Renan demonstra que a convivência e a colaboração dos católicos, mesmo dos que se dizem liberais, ao processo revolucionário baseado na Carta das Liberdades Modernas é impossível.Essaimpossibilidade radica na incompatibilidade estrutural entre o catolicismo e o liberalismo. Ora é precisamente este o núcleo central da Defesa da Carta Encíclica.

Antero caracteriza a encíclica Quanta Cura afirmando tratar-se não de um ataque ao liberalismo, como foi entendida pela opinião liberal, mas sim de uma "condenação justa e lógica. Justa porque parte do tribunal competente e esse tribunal é infallível. Lógica, certa - pois a mão que ata e desata e sem hesitar atina com as portas do céu para as abrir podia tremer, enganar-se ao solver uma difficuldade de terra?" $\left({ }^{70}\right)$, aduz nos capítulos seguintes do seu texto os pressupostos que deram origem áquela condenação.

Ora, são esses pressupostos que encontramos no $\mathrm{Du}$ Libéralisme Clerical, escrito quinze anos antes e em circunstâncias díspares. Antero põe em confronto o Direito Humano em face do Direito Divino $\left({ }^{1}\right)$. "A igreja negará liberdade, direito e ciência: porque essas três flores esplêndidas a embalsamarem o ar da vida, para que brilhassem
(67) Ibidem.
${ }^{68}$ ) Citado em A Espontaneidade, ob. cit., p. 49.
$\left({ }^{69}\right)$ In Ernest Renan, Questions Contemporaines, 3." éd., Paris, Michel Lévy Frères, 1869, pp. 419-460.
$\left({ }^{70}\right)$ In Defesa da Carta Encíclica, p. 8.
( $\left.{ }^{71}\right)$ Ob. cit., expressão de abertura do §, p. 9. 


\section{A Questão Laica na "Quanta Cura"}

ao sol da glória, deviam ter brotado, como lyrios d'amor divino de dentro do coração de Cristo e não do chão escuro da incerta razão humana, sob um céu baço de dúvidas e contradições..." ( $\left.{ }^{2}\right)$. É apresentada a revelação como oposta à razão. É a essência da Igreja, o seu fundamento, o seu passado que a impede de aceitar a nova ideologia.

No Du Libéralisme Clerical lê-se: "le passé étant la loi infranchissable de l'Église, si le passé lui interdit le libéralisme, si elle ne peut sans renier ses décisions antérieures adopter les idées modernes en politique, il sera prouvé que les orthodoxes n'ont pas le droit de parler de liberté, et que s'ils en parlent ils sont des hipocrites ou des hérétiques" $\left({ }^{3}\right)$.

Antero opõe Igreja e mundo moderno: "a ciência é a alma do mundo porque o seu nome diz-se liberdade. $O$ nome da Igreja é authoridade" $\left({ }^{4}\right)$.

Renan, mais demoradamente, detém-se na Carta das Liberdades Modernas: "Existence de la nation à l'état de personne morale ayant des droits comme elle a une résponsabilité. Participation de tous au gouvernement à des degrés divers. Tolérance religieuse universelle Liberté illimitée de la pensée, et par conséquent de la parole et de la presse, dans l'ordre spéculatif" ${ }^{(5)}$. Demonstra como a Igreja tradicional, aliada do poder absoluto $\left({ }^{76}\right)$, detentora de uma estrutura hierática, repressora de toda a tentativa de episcopalismo e de curialismo, não pode aceitar o programa das liberdades modernas, porque o seu passadolho impede: "Ledroit divin du pouvoir établit est une proposition que les docteurs orthodoxes prouvent par l'Écriture" $\left({ }^{7}\right)$.

Esta incompatibilidade do ideário liberal, da nova supranacionalidade com o Catolicismo, que Pio IX condena, Renan demonstra-a através da história.

Antero afirma-a ironizando: "Progressista e homem de tradição! liberal e captivo de Roma! crítico e dogmático! volteriano e asceta! homem de fé e homem de razão! a letra e o espírito! a immobilidade e
$\left.{ }^{(2}\right)$ Ibidem.
( $\left.{ }^{73}\right)$ Ob. cit., p. 423 ss.
( ${ }^{74}$ Ob. cit., p. 10 ss.
( ${ }^{75}$ ) Ob. cit., p. 425 ss.
$\left({ }^{76}\right)$ Ob. cit., p. 434.
( $\left.{ }^{77}\right)$ Ob. cit., p. 426. 
o movimento! a idade média e o futuro! Gregório VII e Washington! Hegel e o Evangelho! a abóbada enfim, da cathedral, fria, escura, estreita, e o céu da vida largo, luminoso e infinito! Que imaginação de poeta colossal fora precisa para criar estas antíteses violentas e disformes" $\left({ }^{78}\right)$.

Enquanto que Renan demonstra, pela doutrina dos Padres da Igreja e pela própria história desta instituição, a impossibilidade da conciliação entre o liberalismo e o catolicismo e, entre este e o liberalismo católico $\left({ }^{79}\right)$, Antero apoda "esta coisa sem nome [que] se chamou racionalismo cristão, catolicismo liberal (...) ignorância e absurdo!" e isto porque "a Igreja é universal - é cathólica - o seu espírito é o absoluto" $\left.{ }^{80}\right)$.

A lógica que Antero elogia na doutrina da Quanta Cura radica aqui mesmo nesta incompatibilidade estrutural - "se não é o filho é o inimigo" $\left({ }^{81}\right)$. Para os dois autores a actuação da Igreja é ditada pela intolerância que a verdade absoluta, transformada em dogma, impõe.

Diz Renan: "ne demandez pas d'abord au catholique cette tolerance intérieur qui est non pas le cepticisme, mais la critique: le catholique la condamne comme mauvaise et impossible (...) aux yeux de l'orthodoxie, en effet, l'hétérodoxe est coupable" $\left({ }^{82}\right)$. Ou mais explicitamente: "On a peur de presser les catholiques (...) il ne faut pas exiger d'eux ce qu'ils ne peuvent donner. Demandez-leur de rennoncer à l'orthodoxie, à la bonne heure; mais ne leur demandez pas de rester orthodoxes et de supporter l'hétérodoxie. Il s'agit lá pour eux d'être ou de n'être pas" $\left({ }^{83}\right)$.

Antero diz simplesmente: "Sejamos ultramontanos muito embora, mas sejamos lógicos (...) Ide! calcae o interesse, o hábito, o amor o que tendes por justiça, o que julgaes ser a razão - mas sêde catholicos ... e sêde coherentes" ( $\left.{ }^{84}\right)$.

Assim, a Defesa da Carta Encíclica é um ataque total à Igreja, em especial, na condenação da civilização moderna, como o autor diz lapi-
$\left({ }^{78}\right)$ Ob. cit., p. 14 ss.
$\left({ }^{79}\right)$ Ob. cit., pp. 425-440.
$\left.{ }^{(80}\right)$ Ob. cit., p. 14.
(8) Ibidem.
(82) Ob. cit., p. 440 ss.
( $\left.{ }^{83}\right)$ Ob. cit., p. 443
(अ4) Ob. cit., p. 15. 


\section{A Questão Laica na "Quanta Cura"}

darmente: "O Christianismo e o mundo actual são incompatíveis e inimigos" $\left({ }^{85}\right)$. Na oposição entre liberdade e dogma, progresso e imobilidade, razão e revelação, que Renan teoriza histórica e doutrinalmente, e que Antero - apóstolo de uma nova religião - postula, encontra-se a lógica de Pio IX que verificando aquela antinomia a condena por se opôr ao catolicismo. Como Antero ironiza, "a authoridade infalível não se defende (...). Fulmina, eis tudo" $\left({ }^{86}\right)$.

\footnotetext{
( $\left.{ }^{85}\right)$ Ob. cit., p. 25.

( $\left.{ }^{86}\right)$ Ob. cit., p. 7.
} 